\title{
The cockle Cerastoderma edule at Northeast Atlantic shores: genetic signatures of glacial refugia
}

\author{
Manuela Krakau • Sabine Jacobsen • \\ Kurt Thomas Jensen · Karsten Reise
}

Received: 7 July 2011/ Accepted: 16 September 2011/Published online: 11 October 2011

(C) Springer-Verlag 2011

\begin{abstract}
The cockle Cerastoderma (Cardium) edule (L.) ranges from NW Africa to northern Scandinavia. Abundance in shallow coastal sediment is often high, and it attracts commercial harvest. In this study, a complex genetic pattern has been revealed by mitochondrial DNA in 383 individuals from 19 sampling sites. Parsimony network analysis of 79 haplotypes identified two dominant central haplotypes separated by low divergence. One is characteristic for a homogenous southwestern group of populations from Africa to the British Isles. The other is characteristic for a heterogeneous northern group with a deviant Arctic population. At the entrance of the Baltic Sea, a mixture zone of the dominant haplotypes was found. The estimated population expansion time for the northern haplotype group predates that of the southwestern one, suggesting northern glacial refugia and a subsequent southern expansion of $C$. edule populations.
\end{abstract}

Communicated by S. Uthicke.

Electronic supplementary material The online version of this article (doi:10.1007/s00227-011-1802-8) contains supplementary material, which is available to authorized users.

M. Krakau $\cdot$ S. Jacobsen $\cdot$ K. Reise $(\bowtie)$

Alfred Wegener Institute for Polar and Marine Research,

Wadden Sea Station Sylt, Hafenstr. 43, 25992 List, Germany

e-mail: karsten.reise@awi.de

\section{K. T. Jensen}

Marine Ecology, Department of Biological Sciences,

University of Aarhus, Ole Worms Allé 1,

Bld. 1135, 8000 Aarhus, Denmark

\section{Introduction}

Quaternary glaciation cycles and corresponding extinctions, contractions into glacial refugia and interglacial expansions of individual species have laid the foundation for present species assemblages at temperate and high latitudes (Hewitt 2000; Martin and McKay 2004; Hoffmann and Sgrò 2011). Large-scale population genetic analysis may detect signatures of these developments. In the simplest scenario with a single glacial refugium below the glaciated area, a linear decrease in genetic diversity toward higher latitudes can be expected. In the Northeast Atlantic, there are, however, several examples where marine species do not conform to this. Two species of seagrass, for example, show highest allelic diversity in the North Sea region (Coyer et al. 2004; Olsen et al. 2004). Several species of benthic macroalgae and invertebrates seem to have survived glaciations in periglacial or cryptic northern refugia (Roman and Palumbi 2004; Hoarau et al. 2007; Maggs et al. 2008; Luttikhuizen et al. 2008; Olsen et al. 2010; Coyer et al. 2011).

In benthic bivalves, no clear evidence for northern glacial refugia has been found so far. However, trans-Arctic pathways from Pacific coasts and dispersal across the northern Atlantic have been inferred from genetic analyses for bivalves. Notable examples are the circumpolar Macoma balthica complex (Luttikhuizen et al. 2003; Nikula et al. 2007) and the closely related mussels Mytilus edulis, M. trossulus and M. galloprovincialis (Riginos and Henzler 2008; Brannock and Hilbish 2010; Väinölä and Strelkov 2011). Patterns in the latter may have been further complicated by human-mediated translocations. Such pathways have been genetically reconstructed for various introduced alien species (e.g., Darling et al. 2008; Reitzel et al. 2008; Reusch et al. 2010; Lejeusne et al. 2011). In the lagoon 
cockle Cerastoderma glaucum, scattered populations are separated into an eastern group with Ponto-Caspian and Aegean Sea haplotypes and a western group from the Mediterranean to the Baltic Sea (Nikula and Väinölä 2003), and peculiar long-distance relationships may have been caused by migrant birds carrying eggs or larvae (Tarnowska et al. 2010).

The common cockle, Cerastoderma (Cardium) edule (L.), on the other hand, occupies a continuous range in shallow water sediments from northern Africa along the eastern Atlantic coasts to northern Norway and Murmansk in the Arctic and is not found in the Mediterranean and Baltic Seas (Brock 1980; Hayward and Ryland 1995). Local populations tend to fluctuate and occasionally collapse due to severe winters, predation, parasites and cockle fishery (Reise 1985; Jensen 1992; Piersma et al. 2001; Strasser 2002; Thieltges 2006; Beukema and Dekker 2006; Kraan et al. 2007). Dispersal in C. edule may last up to 4 weeks, primarily by pelagic larvae and secondarily by drifting juveniles (Creek 1960; Armonies 1994; de Montaudouin et al. 2003). This may usually substitute local losses from nearby sites, leaving little traces in the genetic structure in contrast to large-scale glaciations.

The aim of the present study was to examine the mitochondrial DNA (mtDNA) variability of $C$. edule for signatures of its Pleistocene and postglacial population history. Unlike in mussels and oysters, transfers for culturing purposes between coastal regions have not been practiced to our knowledge. Considering the present distribution range of $C$. edule and the suspected high dispersal capacity (Creek 1960; Boyden 1971), we expected highfrequency southern haplotypes with no or few private haplotypes in the northern range, indicating a southward retreat during last glacial maximum and subsequent recolonization of the northern range. On the other hand, survival in cryptic refugia and periglacial zones during glaciations would be indicated by more complex patterns of the genetic structure. Clarifying the mtDNA phylogeography of $C$. edule may improve our understanding on how modern benthic communities came into existence in a coastal region that has experienced pronounced climatic and topographic change since the Pleistocene.

\section{Materials and methods}

\section{Samples}

Between 2005 and 2007, individuals of $C$. edule were collected from 18 European sampling sites plus one African site (Table 1). Sampling was conducted randomly at the mid-intertidal by hand and rake next to Lagos and Lisbon (Portugal), Dublin (Ireland), Sylt (Germany),
Kristineberg (Sweden) and Bergen (Norway). In addition, specimens from 13 other sites were kindly provided by colleagues following the same sampling protocol. Whole bivalves or parts of soft tissue were preserved immediately in $96-100 \%$ ethanol and were stored at $\leq 4^{\circ} \mathrm{C}$ until further processing. The analyses comprised 383 individuals of C. edule (Table 1).

\section{DNA extraction and PCR}

We extracted total DNA from adductor muscle or foot tissue following the protocol of the QIAGEN ${ }^{\circledR}$ DNeasy Blood and Tissue Kit (Qiagen; Hilden, Germany). A DNA fragment of about 700 base pairs (bp) from the $5^{\prime}$ part of the mitochondrial cytochrome oxidase I (COI) gene was amplified. Polymerase chain reaction (PCR) amplification was performed on the Biometra ${ }^{\circledR}$ Thermal Cycler T1 (Biometra; Göttingen, Germany) as described below.

After receiving the sequencing results of the first PCRs where the primers HCO1490 and HCO2198 from Folmer et al. (1994) were used, a new forward primer was designed: COI5Fc: 5'-CAT AAA GAT ATT GGG ACT TTA TAC- $3^{\prime}$. This forward primer was combined with the published reverse primer (HCO2198: 5'-TAA ACT TCA GGG TGA CCA AAA AAT CA-3') for reliable amplifications. PCR was carried out in $50-\mu \mathrm{L}$ reaction volume with $\sim 150 \mathrm{ng}$ template DNA, $0.2 \mathrm{mM}$ of each dNTP, $0.6 \mu \mathrm{M}$ of each primer, $1.5 \mathrm{mM}$ of $\mathrm{MgCl}_{2}$ and $2.5 \mathrm{U}$ Taq polymerase (Qiagen; Hilden, Germany) in the buffer supplied by the manufacturer. The first denaturation at $94^{\circ} \mathrm{C}$ lasted $2 \mathrm{~min}$, followed by 40 cycles with denaturation at $94^{\circ} \mathrm{C}$ for $60 \mathrm{~s}$, annealing at $50^{\circ} \mathrm{C}$ for $60 \mathrm{~s}$ and extension at $72^{\circ} \mathrm{C}$ for $60 \mathrm{~s}$. Amplification results were confirmed by $1 \%$ agarose gel electrophoresis. Fragments were purified using the QIAquick purification kit (Qiagen; Hilden, Germany). Direct sequencing of PCR products was done in one direction by MWG Biotech (Ebersberg, Germany). Over $25 \%$ of sequences representing singleton haplotypes were tested and all verified after repeating DNA extraction, PCR and additional reverse sequencing. Thus, sequencing errors cannot be entirely excluded but should have no major impact on the results.

Sequence and statistical analyses

Quality of sequencing results was manually checked with the free software CHROMAS Lite 2.01 (Technelysium Pty Ltd), and sequences were aligned using "CLUSTAL W" as implemented in BioEdit (Hall 1999). Haplotype and nucleotide diversity analyses were performed with the software package DnaSP 4.10 (Rozas et al. 2003).

Spatial population structuring was tested using SAMOVA 1.0 (Dupanloup et al. 2002) by maximizing the $F_{\mathrm{CT}}$ 
Table 1 Sampling sites for C. edule
The two-letter code is subsequently used in graphs and text. In the second column, some sites have been grouped for presentation in Fig. 1. The last column indicates the genetic grouping (GG)

\begin{tabular}{|c|c|c|c|c|c|c|c|}
\hline Code & & Location & Country & Latitude & Longitude & Sampling date & GG \\
\hline MO & & Merja Zerga & Morocco & $34^{\circ} 50^{\prime} \mathrm{N}$ & $06^{\circ} 14^{\prime} \mathrm{W}$ & August 2005 & Southwest \\
\hline $\mathrm{AL}$ & $\mathrm{PO}$ & Lagos & Portugal & $37^{\circ} 07^{\prime} \mathrm{N}$ & $08^{\circ} 37^{\prime} \mathrm{W}$ & September 2005 & Southwest \\
\hline $\mathrm{LN}$ & $\mathrm{PO}$ & Lisbon & Portugal & $38^{\circ} 43^{\prime} \mathrm{N}$ & $09^{\circ} 00^{\prime} \mathrm{W}$ & September 2005 & Southwest \\
\hline $\mathrm{AR}$ & FR & Arcachon & France & $44^{\circ} 35^{\prime} \mathrm{N}$ & $01^{\circ} 14^{\prime} \mathrm{W}$ & August 2005 & Southwest \\
\hline RO & FR & Roscoff & France & $48^{\circ} 43^{\prime} \mathrm{N}$ & $03^{\circ} 58^{\prime} \mathrm{W}$ & June 2007 & Southwest \\
\hline $\mathrm{TH}$ & & Southend & England (UK) & $51^{\circ} 28^{\prime} \mathrm{N}$ & $00^{\circ} 42^{\prime} \mathrm{E}$ & March 2007 & Southwest \\
\hline DB & & Dublin & Ireland & $53^{\circ} 19^{\prime} \mathrm{N}$ & $06^{\circ} 12^{\prime} \mathrm{W}$ & August 2005 & Southwest \\
\hline SO & & St. Andrews & Scotland (UK) & $56^{\circ} 21^{\prime} \mathrm{N}$ & $02^{\circ} 50^{\prime} \mathrm{W}$ & August 2006 & Scottish \\
\hline SL & & North Gluss & Scotland (UK) & $60^{\circ} 28^{\prime} \mathrm{N}$ & $01^{\circ} 21^{\prime} \mathrm{W}$ & September 2007 & North \\
\hline TX & WS & Texel & The Netherlands & $53^{\circ} 13^{\prime} \mathrm{N}$ & $04^{\circ} 94^{\prime} \mathrm{E}$ & August 2004 & North \\
\hline LA & WS & Langeoog & Germany & $53^{\circ} 45^{\prime} \mathrm{N}$ & $07^{\circ} 29^{\prime} \mathrm{E}$ & July 2007 & North \\
\hline SY & & Sylt & Germany & $55^{\circ} 01^{\prime} \mathrm{N}$ & $08^{\circ} 26^{\prime} \mathrm{E}$ & September 2005 & North \\
\hline $\mathrm{LF}$ & & Limfjord & Denmark & $56^{\circ} 56^{\prime} \mathrm{N}$ & $09^{\circ} 04^{\prime} \mathrm{E}$ & July 2007 & North \\
\hline NM & SK & Norsminde & Denmark & $56^{\circ} 02^{\prime} \mathrm{N}$ & $10^{\circ} 25^{\prime} \mathrm{E}$ & July 2007 & Skagerrak \\
\hline $\mathrm{KR}$ & SK & Kristineberg & Sweden & $58^{\circ} 14^{\prime} \mathrm{N}$ & $11^{\circ} 26^{\prime} \mathrm{E}$ & July 2006 & Skagerrak \\
\hline FL & SK & Arendal & Norway & $58^{\circ} 26^{\prime} \mathrm{N}$ & $08^{\circ} 48^{\prime} \mathrm{E}$ & August 2005 & Skagerrak \\
\hline $\mathrm{BN}$ & & Bergen & Norway & $60^{\circ} 23^{\prime} \mathrm{N}$ & $05^{\circ} 20^{\prime} \mathrm{E}$ & August 2005 & North \\
\hline $\mathrm{BO}$ & & Bod $\varnothing$ & Norway & $67^{\circ} 17^{\prime} \mathrm{N}$ & $14^{\circ} 37^{\prime} \mathrm{E}$ & August 2005 & North \\
\hline $\mathrm{DZ}$ & & Murmansk & Russia & $69^{\circ} 10^{\prime} \mathrm{N}$ & $36^{\circ} 05^{\prime} \mathrm{E}$ & August 2007 & Arctic \\
\hline
\end{tabular}

value, which is the proportion of total genetic variance due to differences between groups of populations. Significance level was determined based on 1,000 random permutations of the data. A slightly modified structure based on geographic vicinity of sampling sites was additionally tested with the analysis of molecular variance (AMOVA: Excoffier 1995), as implemented in the program Arlequin (Version 3.1; Excoffier et al. 2005).

Pairwise $F_{\mathrm{ST}}$ values were calculated in Arlequin using uncorrected pairwise distances. To assess whether gene flow correlates with geographic distance ("isolation-bydistance" model), the matrix of pairwise $F_{\mathrm{ST}}$ values to the geographic distance matrix was tested using a Mantel test implemented in Arlequin. The statistical significance of the correlation coefficient was determined by conducting Mantel tests on 5,000 random permutations of the data set. Geographic distances between populations as estimates of dispersal ranges were calculated in kilometers as shortest along-shoreline and across-water distance using ArcGIS 9.2 (ESRI; Kranzberg, Germany).

Since trees are less adequate to visualize intraspecific phylogenies with small genetic distances, a statistical parsimony haplotype network was constructed by the computer program TCS v1.21 (Clement et al. 2000). Neutrality tests and mismatch analyses were performed with the software package DnaSP 4.10. Obtained graphical outputs were used to illustrate demographic model fit. Additionally, the time frame of population expansion $(t)$ was estimated after Rogers (1995) applying the demographic parameters $\tau$ ("tau") given by DnaSP 4.10. The equation $t=\tau / 2 \mu k$ (see Rogers and Harpending 1992) was used with $\tau$ as moment estimator of time to expansion, $\mu$ as per year probability of an individual nucleotide site to mutate and $k$ as length of sequence investigated.

\section{Results}

\section{Genetic richness}

The aligned data set of COI sequences derived from 383 Cerastoderma edule individuals consisted of 582 nucleotide positions with $78(13 \%)$ variable positions. The 79 COI haplotypes identified (Genbank Accession Numbers: FJ403245-FJ403323) displayed between 0.17 and $1.37 \%$ nucleotide differences. Haplotype and nucleotide diversity varied between sampling sites, with generally high haplotype diversity but low nucleotide diversity (Table 2).

The highest diversity index values were found at Bodø at the northern Norwegian coast (BO: $h=0.931$, $\pi=0.00646$; Table 2). On average, haplotype and nucleotide diversity were observed to be higher in northern edge populations (SL, BO: $h>0.700$ ) than in the southern Atlantic sites (MO and AL: $h<0.430$ ). The samples from Roscoff (RO) and Southend ( $\mathrm{TH})$ exhibited relatively high diversity values compared to more southern sites of the Atlantic region. The lowest genetic diversity value was found in the population from St. Andrews (SO: $h=0.140$, Table 2), and this Scottish sample was without private haplotypes. 
Table 2 Genetic diversity indices for cockle populations
Standard deviation (SD) is given for $h$ and $\pi$. Code for sites as in Table 1

$N$ number of cockles investigated

\begin{tabular}{|c|c|c|c|c|c|c|}
\hline Code & $N$ & $\begin{array}{l}\mathrm{H}_{\mathrm{t}} \\
\text { Number of all } \\
\text { haplotypes }\end{array}$ & $\begin{array}{l}\mathrm{H}_{\mathrm{u}} \\
\text { Number } \\
\text { of unique } \\
\text { haplotypes }\end{array}$ & $\begin{array}{l}\text { S } \\
\text { Number of } \\
\text { polymorphic } \\
\text { sites }\end{array}$ & $\begin{array}{l}\text { h } \\
\text { Haplotype } \\
\text { diversity (SD) }\end{array}$ & $\begin{array}{l}\pi \\
\text { Nucleotide } \\
\text { diversity } \\
(\mathrm{SD}) \times 10^{2}\end{array}$ \\
\hline MO & 21 & 5 & 1 & 4 & $0.424(0.131)$ & $0.105(0.037)$ \\
\hline $\mathrm{AL}$ & 21 & 6 & 2 & 6 & $0.429(0.134)$ & $0.113(0.043)$ \\
\hline $\mathrm{LN}$ & 10 & 3 & 1 & 5 & $0.511(0.164)$ & $0.225(0.089)$ \\
\hline $\mathrm{AR}$ & 13 & 3 & 1 & 4 & $0.410(0.154)$ & $0.128(0.067)$ \\
\hline RO & 23 & 10 & 6 & 14 & $0.731(0.099)$ & $0.264(0.075)$ \\
\hline DB & 23 & 8 & 6 & 9 & $0.526(0.126)$ & $0.135(0.046)$ \\
\hline $\mathrm{TH}$ & 21 & 9 & 5 & 11 & $0.729(0.102)$ & $0.263(0.064)$ \\
\hline $\mathrm{SO}$ & 28 & 3 & 0 & 3 & $0.140(0.087)$ & $0.048(0.034)$ \\
\hline SL & 20 & 6 & 1 & 7 & $0.705(0.086)$ & $0.336(0.070)$ \\
\hline $\mathrm{TX}$ & 20 & 6 & 2 & 6 & $0.447(0.137)$ & $0.176(0.066)$ \\
\hline LA & 21 & 5 & 3 & 10 & $0.486(0.124)$ & $0.191(0.074)$ \\
\hline SY & 19 & 12 & 7 & 17 & $0.901(0.059)$ & $0.428(0.074)$ \\
\hline $\mathrm{LF}$ & 19 & 9 & 4 & 8 & $0.772(0.094)$ & $0.350(0.058)$ \\
\hline NM & 20 & 8 & 2 & 11 & $0.863(0.049)$ & $0.553(0.053)$ \\
\hline $\mathrm{KR}$ & 20 & 7 & 1 & 8 & $0.642(0.118)$ & $0.352(0.093)$ \\
\hline FL & 20 & 8 & 2 & 13 & $0.868(0.044)$ & $0.524(0.063)$ \\
\hline $\mathrm{BN}$ & 22 & 8 & 2 & 14 & $0.771(0.080)$ & $0.402(0.082)$ \\
\hline $\mathrm{BO}$ & 22 & 11 & 2 & 15 & $0.931(0.028)$ & $0.646(0.072)$ \\
\hline $\mathrm{DZ}$ & 20 & 8 & 7 & 13 & $0.589(0.130)$ & $0.223(0.083)$ \\
\hline Average & 20.2 & 7.1 & 2.8 & 9.4 & 0.625 & 0.287 \\
\hline ALL & 383 & 79 & 54 & 78 & $0.866(0.012)$ & $0.511(0.017)$ \\
\hline
\end{tabular}

Spatial grouping due to regional haplotype dominance

Of the 79 COI variants identified for C. edule, only 15 haplotypes occurred at least at two localities (=shared haplotypes, Table 3). Nine haplotypes repeated in several individuals at one sampling site only. Of all haplotypes, $70 \%$ were found only once at all. Thus, 55 haplotypes represented real singletons. Two haplotypes, named $\mathrm{S}$ and $\mathrm{N}$, appeared at twelve and ten sampling sites, representing 28.5 and $20.4 \%$ of individuals in the total sample, respectively (Table 3 ). The dominance of the S-haplotype and the simultaneous absence of the N-type along the southern Atlantic coast including the Irish and the African sites were apparent when haplotype frequencies were visualized on a geographic map (Fig. 1). Atlantic sites showed high numbers of local haplotypes next to the English Channel (Fig. 1). The haplotype $\mathrm{N}$ occurred in all northern populations except at the northernmost site DZ in the Barents Sea. In the North Sea, Norwegian Sea and Arctic area, $C$. edule populations were characterized by several shared northern haplotypes and the absence of the S-type, while a mixture of northern and southern haplotypes was observed for three sites next to the Baltic Sea entrance (Table 3, NM, KR, FL, summarized as SK in Fig. 1).

Spatial AMOVA (SAMOVA) was used to statistically define groups of populations that are geographically homogeneous and maximally differentiated from each other. Subdivisions were tested for two to seven geographic groups (see Table S1). The analysis confirmed the two groups representing several sampling sites (named "southwestern" and "northern") that were mainly defined by the presence or absence of one dominant haplotype. In addition, two single sites (SO and DZ) were explicitly separated from all others (Table S1, $F_{\mathrm{CT}}$ : $0.514, p<0.001$ ). They contained one dominant haplotype that was shared with no more than two other sites (Table 3). A significant amount of variation occurred between the four statistically distinct groups (Table S2, AMOVA: $48.9 \%, p<0.001)$, while within-groups variation was low (6.3\%). The southwestern group comprised the African and the southwestern European sites from Portugal to the British Isles dominated by haplotype S $(66.7 \%)$. Within the northern group, all sites northeast of the English Channel region, the haplotype $\mathrm{N}$ was the characteristic and most common haplotype (35.0\%), except at SO and DZ (Fig. 1). The number of haplotypes found exclusively either in southwestern or in northern cockle populations was high (Table 3).

Isolation by distance among northern populations

Focusing on the relationship between geographic and genetic distances between all 19 sampling sites along the 
Table 3 Frequency of shared haplotypes in C. edule populations

$N_{\text {SH }}$ Number of individuals that share haplotypes with cockles from $\geq 2$ sites and $N_{\mathrm{LH}}$ Number of individuals with local haplotypes. S, N, I-XIII haplotype identifier

\begin{tabular}{|c|ccccc|c|cccccccc|c|c|c|}
\hline Code & S & I & II & III & IV & $\mathbf{V}$ & $\mathbf{N}$ & VI & VII & VIII & $\mathbf{I X}$ & $\mathbf{X}$ & $\mathbf{X I}$ & $\mathbf{X I I}$ & $\mathbf{X I I I}$ & $\mathbf{N}_{\mathbf{S H}}$ & $\mathbf{N}_{\mathbf{L H}}$ \\
\hline MO & 16 & 1 & - & 2 & 1 & - & - & - & - & - & - & - & - & - & - & 20 & 1 \\
AL & 16 & - & 1 & 1 & 1 & - & - & - & - & - & - & - & - & - & - & 19 & 2 \\
LN & 7 & - & - & - & - & - & - & - & - & - & - & - & - & - & - & 7 & 3 \\
AR & 10 & - & - & 2 & - & - & - & - & - & - & - & - & - & - & - & 12 & 1 \\
RO & 12 & - & - & 2 & - & - & - & 1 & - & - & - & - & - & - & - & 15 & 8 \\
TH & 11 & - & 2 & - & - & - & - & 1 & - & - & - & - & - & - & - & 14 & 7 \\
DB & 16 & 1 & - & - & - & - & - & - & - & - & - & - & - & - & - & 17 & 6 \\
\hline SO & 1 & - & - & - & - & 26 & - & - & - & - & 1 & - & - & - & - & 28 & 0 \\
\hline SL & 1 & - & - & - & - & - & 10 & 1 & 1 & - & - & - & - & - & 5 & 18 & 2 \\
TX & - & - & - & - & - & - & 15 & 1 & - & - & 1 & - & 1 & - & - & 18 & 2 \\
LA & - & - & - & - & - & - & 15 & 3 & - & - & - & - & - & - & - & 18 & 3 \\
SY & - & - & - & - & - & - & 6 & - & 1 & - & - & 2 & 1 & - & - & 10 & 9 \\
LF & - & - & - & 1 & - & - & 9 & 1 & - & - & 3 & 1 & - & - & - & 15 & 4 \\
NM & 2 & - & - & - & - & - & 4 & 2 & - & 6 & 3 & - & - & 1 & - & 18 & 2 \\
KR & 12 & - & - & - & - & - & 1 & 1 & - & 2 & 2 & 1 & - & - & - & 19 & 1 \\
FL & 5 & - & 2 & - & - & - & 5 & - & - & 2 & 3 & - & - & 1 & - & 18 & 2 \\
BN & - & - & - & - & - & 1 & 10 & 2 & 1 & 2 & - & - & - & - & - & 16 & 6 \\
BO & - & - & - & - & - & 2 & 3 & - & 2 & 1 & - & - & - & - & 4 & 12 & 10 \\
\hline DZ & - & - & - & - & - & - & - & - & - & - & - & - & - & - & 13 & 13 & 7 \\
\hline All & 109 & 2 & 5 & 8 & 2 & 29 & 78 & 13 & 5 & 13 & 13 & 4 & 2 & 2 & 22 & 307 & 76 \\
\hline
\end{tabular}

northeastern Atlantic shoreline, the matrix correlation coefficient indicated that about $20 \%$ of the variation in pairwise genetic distances of uncorrected $F_{\mathrm{ST}}$ values (Table 4) could be attributed to geographic distances between pairs of sites (Mantel test: $R=0.448, p<0.001$ ). Repeating the Mantel test with the subset of eleven northern populations, the correlation coefficient $\mathrm{R}$ increased to $0.620(p<0.05)$. This implies that $38 \%$ of variation may be explained by geographic differentiation and indicates isolation by distance (IBD) for northern sampling sites, while the analysis of southwestern populations lacked any significant support for IBD $(R=0.113$, $p=0.300$ ).

Phylogenetic and demographic approach

Further insights into the genetic population structure of C. edule were provided by the application of a parsimony network analysis of the 79 individual haplotypes (Fig. 2). Differentiation of the geographic groups on nucleotide level was not well pronounced, since the dominant haplotype $\mathrm{S}$ in Atlantic populations was separated from haplotype $\mathrm{N}$ by only three mutational steps $(0.51 \%)$. However, the network demonstrated fundamental differences between the associated haplotype complexes. The genealogical relationships between northern haplotypes (gray, Fig. 2) were less well resolved than those of southwestern ones (white, Fig. 2). Within the northern cluster, most of the haplotypes of DZ (black, Fig. 2) form an Arctic minicluster around haplotype XIII. In contrast, the southwestern populations displayed shallow divergence among haplotypes. Most haplotypes differentiate only by a singlenucleotide substitution from the dominant haplotype S, which consequently occupies a central position in a star-like pattern. Noticeable is a close relationship of the predominant Scottish haplotype $\mathrm{V}$ to the common southwestern haplotype S (Fig. 2).

The high number of singleton haplotypes (Table 3 ) and the star-like phylogenetic pattern (Fig. 2) indicate an expansion in the effective population size of the cockle $C$. edule in the recent past, which was supported by neutrality tests (Table 5). Tajima's $D$ and Fu's $F$ s statistics were negative for the southwestern and the northern group and differed significantly from expectations under a neutral model of evolution assuming constant population size (Table 5). Testing the growth-decline model for the southwestern populations, the unimodal curve in Fig. 3 supported the assumption of a recent rapid population expansion suggested by the strong clustering of the southern haplotypes in a single star-like pattern (Fig. 2). When the populations FL, KR and NM of the Skagerrak area, which were conspicuous because of the occurrence of the S-haplotype, are pooled for Tajima's $D$ and mismatch distribution analysis, a non-significant, negative value (Table 5) and a multimodal topology (Fig. 3) indicate an equilibrium state or secondary contact zone. However, this local grouping is not supported by SAMOVA tests.

The demographic parameters of the southwestern ( $\tau=0.29)$ and northern group $(\tau=1.84)$ are used to estimate the time since regional population expansion (Table 5). Considering the sequence length of $582 \mathrm{bp}$ and a mutation rate $\mu$ of $2.5 \%$ per million years (see Nikula and Väinölä 2003), the start for an expansion for the southwestern group is set to about 10,000 years BP. The northern population expansion is calculated to about 63,000 years BP. Even when the peculiar Skagerrak 
Fig. 1 COI haplotypes of C. edule along Northeast Atlantic shoreline. Adjacent sites with very similar haplotype occurrence are pooled for clarity of the graph (see Table 1).

Haplotype S occurs

predominantly at southwestern sites that are separated by a dashed line from northern sites with haplotype N. Non-colored parts of pies refer to local haplotypes. For haplotype identifiers N, S and I-XIII, see Table 3

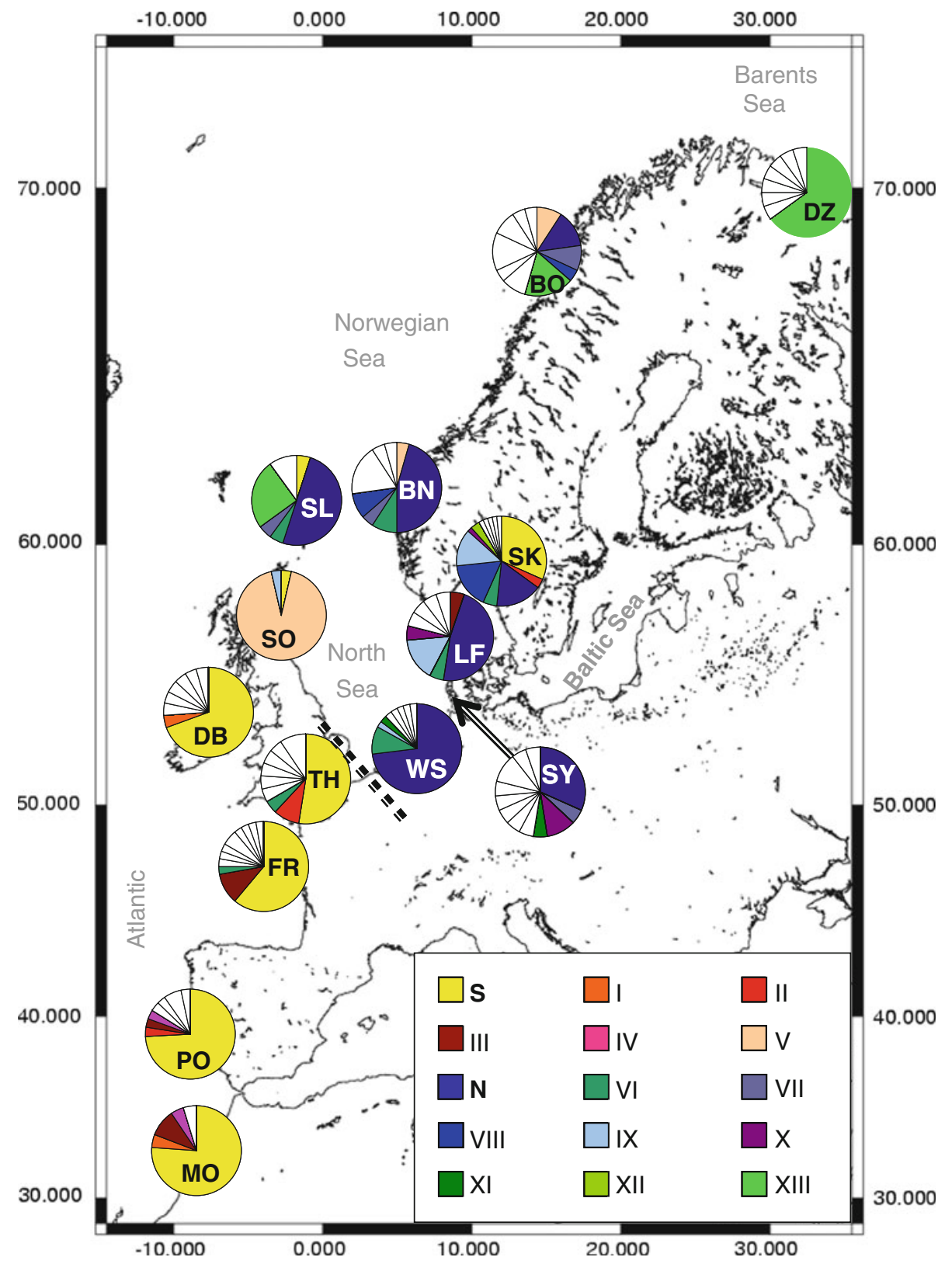

populations, where both most abundant haplotypes occur, are excluded, the estimate for the northern expansion $\left(\mathrm{N}^{\prime}\right.$ : $\tau=1.22)$ is still much longer ago $(42,000$ years BP) than for the southwestern one.

\section{Discussion}

The genetic structure of Cerastoderma edule with its northern and southwestern groups of populations along the Northeast Atlantic coast suggests two historically separated populations during low sea-level stands of the last glaciation. High genetic diversity detected at North Sea and Scandinavian sites in contrast to the low diversity and differentiation in the southwestern cockle populations further supports a scenario of northern glacial refugia.

Our initial expectation of a simple phylogeographic pattern in $C$. edule with diverse southern populations and reduced genetic variety in the North, indicative of northward postglacial recolonization from southern refugia, was not met by the results. It can be inferred that at least one ancestral population has managed to survive somewhere in or near to the North Sea region throughout the last glaciation. Genetic heterogeneity in the northern group of populations suggests a metapopulation structure during the latest glacial period. This is supported by $38 \%$ of genetic variation between sampling sites in the northern group explained by isolation by distance, while 
Table 4 Pairwise $F_{S T}$ values between sample sites

\begin{tabular}{lrrrrrrrrrrrrrrrrrrrrrrr}
\hline & MO & AL & LN & AR & RO & DB & TH & TX & LA & SY & LF & NM & KR & SO & SL & FL & BN & BO & DZ \\
\hline MO & & - & - & - & - & - & - & + & + & + & + & + & + & + & + & + & + & + & + \\
AL & -1.2 & & - & - & - & - & - & + & + & + & + & + & + & + & + & + & + & + & + \\
LN & 10.0 & 7.2 & & - & - & - & - & + & + & + & + & + & - & + & + & + & + & + & + \\
AR & -2.4 & -1.5 & 0.3 & & - & - & - & + & + & + & + & + & - & + & + & + & + & + & + \\
RO & 0.8 & 0.2 & 3.3 & -0.9 & & - & - & + & + & + & + & + & - & + & + & + & + & + & + \\
DB & 3.3 & 0.3 & 6.0 & 1.6 & 0.1 & & - & + & + & + & + & + & - & + & + & + & + & + & + \\
TH & 6.3 & 3.4 & 5.3 & 3.4 & 1.1 & 2.0 & & + & + & + & + & + & - & + & + & + & + & + & + \\
TX & 74.4 & 73.6 & 68.1 & 71.9 & 61.0 & 70.9 & 59.1 & & - & - & - & - & + & + & - & - & - & - & + \\
LA & 75.5 & 74.9 & 69.5 & 73.0 & 63.4 & 72.4 & 61.5 & -0.6 & & - & - & + & + & + & - & + & - & + & + \\
SY & 58.1 & 57.6 & 49.9 & 53.3 & 47.8 & 55.5 & 44.5 & 0.5 & 2.5 & & - & - & + & + & - & - & - & - & + \\
LF & 56.8 & 56.1 & 49.3 & 52.3 & 44.9 & 54.1 & 42.0 & 4.3 & 1.1 & 1.7 & & - & + & + & - & - & - & + & + \\
NM & 49.9 & 48.6 & 41.4 & 44.6 & 40.7 & 47.1 & 37.7 & 12.5 & 14.9 & 9.8 & 6.6 & & - & + & - & - & - & - & + \\
KR & 15.8 & 12.9 & 11.7 & 12.0 & 7.1 & 11.0 & 3.9 & 42.6 & 46.6 & 30.4 & 24.6 & 19.8 & & + & + & - & + & + & + \\
SO & 67.9 & 66.2 & 63.6 & 67.6 & 50.9 & 62.9 & 52.4 & 84.2 & 84.0 & 71.2 & 71.9 & 63.9 & 50.2 & & + & + & + & + & + \\
SL & 63.6 & 62.9 & 55.8 & 59.4 & 52.3 & 60.5 & 50.0 & 5.7 & 7.2 & 2.9 & 8.0 & 13.7 & 35.7 & 75.5 & & - & - & - & + \\
FL & 31.8 & 30.3 & 24.9 & 26.9 & 22.6 & 28.6 & 18.6 & 15.3 & 20.3 & 9.2 & 3.7 & 3.8 & 3.8 & 53.7 & 13.9 & & - & + \\
BN & 61.5 & 60.9 & 54.1 & 57.2 & 51.6 & 59.0 & 49.3 & 2.2 & 2.0 & 2.2 & 6.3 & 7.6 & 34.7 & 72.4 & 6.3 & 12.6 & + \\
BO & 53.9 & 53.1 & 45.8 & 48.8 & 46.5 & 51.9 & 44.1 & 7.7 & 8.5 & 6.2 & 8.9 & 4.8 & 30.3 & 64.0 & 4.3 & 12.1 & 5.3 & - \\
DZ & 83.3 & 82.9 & 78.5 & 81.3 & 75.4 & 81.6 & 74.6 & 60.9 & 59.9 & 47.5 & 53.9 & 50.2 & 66.5 & 88.7 & 38.1 & 53.0 & 50.5 & 34.1 & + \\
\hline
\end{tabular}

Values $\left(* 10^{-2}\right.$, below diagonal) with significance after Bonferroni correction indicated by $+\left(p_{B} \leq 0.003\right.$, above diagonal). Code for sites as in Table 1

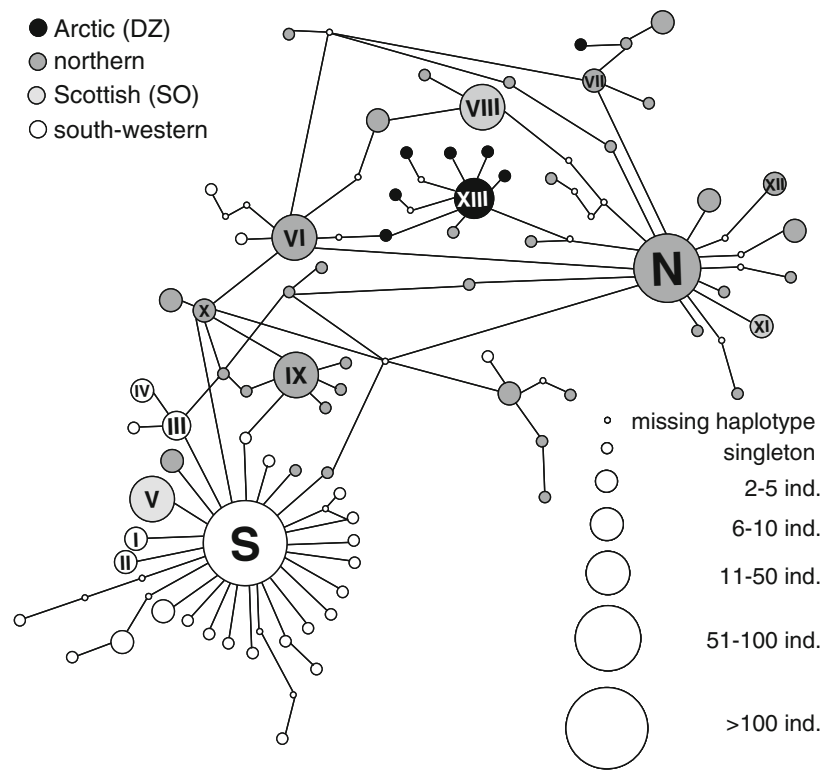

Fig. 2 Minimum spanning network for the 79 COI haplotypes of C. edule. Haplotypes shared between two or more sites are labeled (S, N and I-XIII). Each step along a lineage represents a single mutation. Small open circles indicate missing haplotypes. Color codes of haplotypes correspond to their occurrence in the four spatial groups (as shown)

southwestern populations do not display such geographical structuring.

A relatively high genetic diversity in the North Sea region is also known from two species of seagrass, Zostera marina and Z. noltii, which like C. edule occur on intertidal and shallow subtidal sedimentary bottoms (Olsen et al. 2004; Coyer et al. 2004). The more recent origin and the genetic homogeneity of the southwestern group reject the possibility of a southward retreat of $C$. edule during glaciations. Instead, there might have been a periglacial refugium west of the English Channel from where a southward extension has commenced well after the last glacial maximum. This would fit with the observation that populations in this area display higher diversity indices than other populations within the southwestern group. Survival during the last glaciation somewhere between Ireland and Brittany has also been assumed for the macroalgae Fucus serratus, Palmaria palmata and Ascophyllum nodosum (Maggs et al. 2008; Olsen et al. 2010). However, these rocky shore populations do not share a common habitat with $C$. edule and their refugial vicinity might be a mere coincidence (Marko et al. 2010).

In conclusion, a simple scenario of southward retreat during glaciation, followed by a northward recolonization after the present interglacial commenced, can be rejected for $C$. edule. Although this is the most common pattern for terrestrial species (Hewitt 2000), marine benthos shows other patterns as well (Marko et al. 2010). Northern cryptic refugia and southern periglacial refugia during glaciation provide a better match with the phylogeography inferred from our analyses. However, as the southwestern group of C. edule seems younger than the northern group, northern 
Table 5 Neutrality tests and population demographic parameters for spatial groups in the population size model

\begin{tabular}{|c|c|c|c|c|c|}
\hline \multirow[t]{2}{*}{ Spatial groups } & \multirow[t]{2}{*}{ Number of sequences } & \multicolumn{2}{|c|}{ Neutrality tests } & \multicolumn{2}{|c|}{ Demographic parameters } \\
\hline & & Tajima' s $D$ & Fu's $F$ s & $\tau$ & $\theta_{\mathrm{i}}$ \\
\hline Southwest & 132 & $-2.62 * * *$ & -4.17 & 0.29 & 0.75 \\
\hline SO & 28 & -1.53 n.s. & -1.06 & 0.00 & 0.58 \\
\hline North & 203 & $-1.85^{*}$ & -39.89 & 1.84 & 0.79 \\
\hline North' $^{\prime}$ & 143 & $-1.96 *$ & -36.13 & 1.22 & 1.01 \\
\hline Skagerrak & 60 & -1.97 n.s. & -1.97 & 1.94 & 1.94 \\
\hline $\mathrm{DZ}$ & 20 & $-2.34 * *$ & -3.86 & 0.11 & 1.19 \\
\hline All populations & 383 & $-2.21 * *$ & -94.38 & 1.99 & 0.97 \\
\hline
\end{tabular}

$\tau$, moment estimator of time to expansion; $\theta_{\mathrm{i}}$, mutation parameter for initial populations. To show the special case of the Skagerrak (FL, KR and $\mathrm{NM}$ ), it was calculated separately from the other northern sites (North')

n.s. not significant; * $p<0.05 ; * * p<0.01 ; * * * p<0.001$

Fig. 3 Mismatch distribution analysis. The growth-decline model was applied for two geographic groups. The population of St. Andrews (SO) is excluded from the analyses. Exp expected values and $O b s$ observed values. $N$ number of individuals
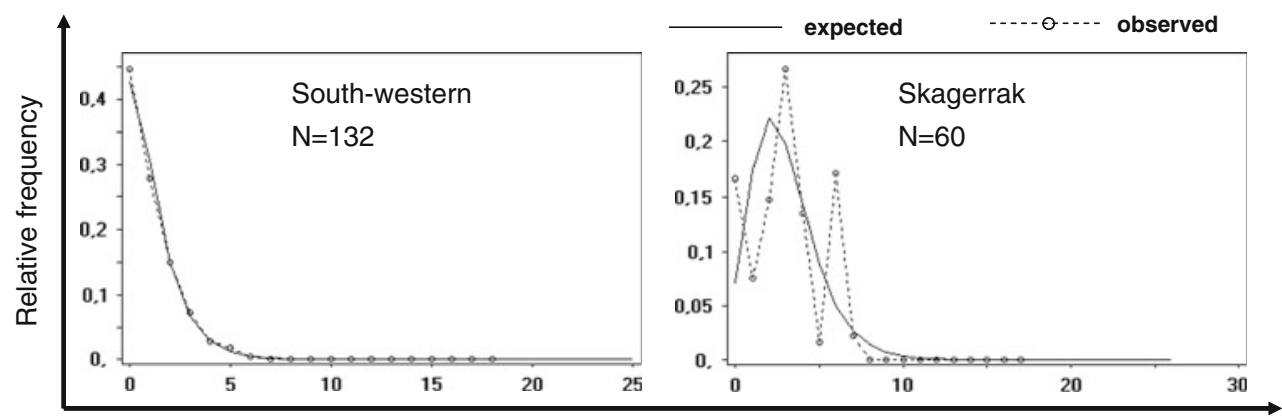

Number of pairwise differences survival combined with southern extinction during the last glacial cannot be rejected. The isolated occurrence of the central haplotype of the southwestern group mixed with haplotypes of the northern group at three sites in the Skagerrak/Kattegat region may be interpreted as a remnant of previously separated populations. The deviant population at Murmansk points to the possible existence of a distinct Arctic group of $C$. edule, but more sampling would be required to answer this question.

Besides the correspondence between $C$. edule and the two seagrass species with high genetic diversity in the North Sea, there is also some similarity with two other coastal bivalves. Mytilus edulis shows patterns of mtDNA which indicate survival in glacial refugia within its present range of the Atlantic North American coastline (Riginos and Henzler 2008). In Europe, the regions west and south of the English Channel are dominated by M. galloprovincialis and east and north of this channel by $M$. edulis (Smietanka et al. 2004). The boundary between the two groups of populations in $C$. edule also coincides with the English Channel. In Macoma balthica rubra, a southern and a northern group mix in the North Sea and Kattegat region and multiple glacial refugia may have existed in the northern group of this subspecies (Nikula et al. 2007). A common predator on coastal bivalve species, the crab
Carcinus maenas, is also subdivided into northern and southwestern populations along the Atlantic shores of Europe (Roman and Palumbi 2004; Darling et al. 2008).

In view of the dramatic drop in sea level during glaciations, when most of the North Sea region turned into land (Gaffney et al. 2009), the most parsimonious assumption is that coastal bivalves such as $C$. edule took refuge in ecologically productive polynyas (unfrozen areas surrounded by sea ice) between Scottish and Fennoscandian ice sheets. Another potential glacial refugial zone might have been the Celtic Sea southwest of the British ice sheet (Ménot et al. 2006). C. edule performs best in non-stagnant water between 10 and $20^{\circ} \mathrm{C}$ but survives a wide range of $0-43^{\circ} \mathrm{C}$ (e.g., Ansell et al. 1981; Wilson 1981; Strasser et al. 2001; Genelt-Yanovskiy et al. 2010). Therefore, temperature alone is unlikely to drive this species to extinction as long as partial populations can survive at greater depth subtidally to avoid extreme temperatures of the intertidal zone (e.g., Eisma 1966; Dörjes et al. 1986; Dekker 1989; Bazairi et al. 2003; Sousa et al. 2006). Gradients from shallow to deep sedimentary bottoms were probably at all times rather common along European coasts to provide habitat for persistent populations of $C$. edule.

Our findings show that the COI gene can be a potentially useful locus for population genetic studies. However, it has 
to be mentioned that the utility of COI mtDNA markers for population genetic purposes is limited by potential deviation from neutrality, overestimation of genetic drift due to smaller effective population size and limited amounts of genetic variation (e.g., Ballard and Whitlock 2004; Held and Leese 2007). This may cause bias in selectively neutral population processes like migration and drift (reviewed by Zhang and Hewitt 2003), and analyses based on multilocus genotypes are highly desirable for cockle phylogeography in the future.

\section{Conclusion}

With Cerastoderma edule as a further example, we support the assumption that North Sea benthic species survived European glaciations in cryptic refugia or periglacial zones. We found no evidence for a species complex, like in the genera Mytilus and Macoma, or a deep separation of phylogeographic groups like in the sister species $C$. glaucum. However, a heterogeneous northern and a homogeneous southwestern group of populations are distinguished in $C$. edule. Their intergradation needs further research as does the possible existence of an Arctic group.

Acknowledgments For sampling support, we thank colleagues involved in the two European exchange projects, French National Coastal Environment Programme (PNEC) and European MarBEF Network of Excellence "Marine Biodiversity and Ecosystem Functioning". MK appreciates the cordial invitation to the laboratories of H. Cabral, S. Mortensen and J. Wilson. MK likes to thank following people for support in laboratory and field work: $H$. Halliger, G. Czichy, J. Kochmann, V. Liebich, J. F. Marques, B. Regenfuß and A. Schlüssel. The study was partly supported by the MarBEF Network funded by the European Community's Sixth Framework Programme (contract no. GOCE-CT-2003-505446). We thank Mathias Wegner and the anonymous reviewers whose comments substantially improved the manuscript.

\section{References}

Ansell AD, Barnett PRO, Bodoy A, Massé H (1981) Upper temperature tolerances of some European molluscs. Mar Biol 65:177-183

Armonies W (1994) Turnover of postlarval bivalves in sediments of tidal flats in Königshafen (German Wadden sea). Helgol Mar Res 48:291-297

Ballard JW, Whitlock MC (2004) The incomplete natural history of mitochondria. Mol Ecol 13:729-744

Bazairi H, Bayed A, Glemarec M, Hily C (2003) Spatial organisation of macrozoobenthic communities in response to environmental factors in a coastal lagoon of the NW African coast (Merja Zerga, Morocco). Oceanol Acta 26:457-471

Beukema JJ, Dekker R (2006) Annual cockle Cerastoderma edule production in the Wadden Sea usually fails to sustain both wintering birds and commercial fishery. Mar Ecol Prog Ser 309:189-204
Boyden CR (1971) A comparative study of the reproductive cycles of the cockles Cerastoderma edule and C. glaucum. J Mar Biol Assoc UK 51:605-622

Brannock PM, Hilbish TJ (2010) Hybridization results in high levels of sterility and restricted introgression between invasive and endemic marine blue mussels. Mar Ecol Prog Ser 406:161-171

Brock V (1980) The geographical distribution of Cerastoderma (Cardium) edule (L) and C lamarcki (Reeve) in the Baltic and adjacent seas related to salinity and salinity fluctuations. Ophelia 19:207-214

Clement M, Posada D, Crandall KA (2000) TCS: a computer program to estimate gene genealogies. Mol Ecol 9:1657-1659

Coyer JA, Peters AF, Stam WT, Olsen JL (2004) Population genetics of Zostera noltii (dwarf eelgrass) throughout its biogeographic range. Mar Ecol Prog Ser 281:51-62

Coyer JA, Hoarau G, Van Schaik J, Luijckx P, Olsen JL (2011) TransPacific and trans-Arctic pathways of the intertidal macroalga Fucus distichus L. reveal multiple glacial refugia and colonizations from the North Pacific to the North Atlantic. J Biogeogr 38(4):756-771

Creek GA (1960) The development of the lamellibranch Cardium edule. Proc Zool Soc Lond 135:243-260

Darling JA, Bagley MJ, Roman J, Telpot CK, Geller JB (2008) Genetic patterns across multiple introductions of the globally invasive crab genus Carcinus. Mol Ecol 17:4992-5007

de Montaudouin X, Bachelet G, Sauriau PG (2003) Secondary settlement of cockles Cerastoderma edule as a function of current velocity and substratum: a flume study with benthic juveniles. Hydrobiologia 503:103-116

Dekker R (1989) The macrozoobenthos of the subtidal western Dutch Wadden Sea. I. Biomass and species richness. Neth J Sea Res 23:57-68

Dörjes J, Michaelis H, Rhode B (1986) Long-term studies of macrozoobenthos in intertidal and shallow subtidal habitats near the island of Norderney (East Frisian coast, Germany). Hydrobiologia 142:217-232

Dupanloup I, Schneider S, Excoffier L (2002) A simulated annealing approach to define the genetic structure of populations. Mol Ecol 11:2571-2581

Eisma D (1966) The distribution of benthic marine molluscs off the main Dutch coast. Neth J Sea Res 3:107-163

Excoffier L (1995) AMOVA Analysis of Molecular Variance, Version 1.55. University of Geneva, Switzerland

Excoffier L, Laval G, Schneider S (2005) Arlequin ver. 3.0: an integrated software package for population genetics data analysis. Evol Bioinform Online 1:47-50

Folmer O, Black M, Hoeh R, Lutz R, Vrijenhoek R (1994) DNA primers for amplification of mitochondrial cytochrome c oxidase subunit I from diverse metazoan invertebrates. Mol Mar Biol Biotechnol 3:294-299

Gaffney V, Fitch S, Smith D (2009) Europe's lost world: the rediscovery of Doggerland. CBA research report 160, York

Genelt-Yanovskiy EA, Poloskin A, Granovitch A, Nazarova S, Strelkov P (2010) Population structure and growth rates at biogeographic extremes: a case study of the common cockle. Cerastoderma edule (L.) in the Barents Sea. Mar Poll Bull 61:247-253. doi:10.1016/j.marpolbul.2010.02.021

Hall TA (1999) BioEdit: a user-friendly biological sequence alignment editor and analysis program for Windows 95/98/NT. Nucleic Acids Symp Ser 41:95-98

Hayward PJ, Ryland JS (1995) Handbook of the marine fauna of north-west Europe. Oxford University Press, Oxford

Held C, Leese F (2007) The utility of fast evolving molecular markers for studying speciation in the Antarctic benthos. Pol Biol 30:513-521 
Hewitt GM (2000) The genetic legacy of the Quaternary ice ages. Nature 405:907-913

Hoarau G, Coyer JA, Veldsink JH, Stam WT, Olsen JL (2007) Glacial refugia and recolonization pathways in the brown seaweed Fucus serratus. Mol Ecol 16:3606-3616

Hoffmann AA, Sgrò CM (2011) Climate change and evolutionary adaptation. Nature 470:479-4485

Jensen KT (1992) Macrozoobenthos on an intertidal mudflat in the Danish Wadden Sea-comparisons of survey in the 1930s, 1940s and 1980s. Helgol Meeresunters 46:363-376

Kraan C, Piersma T, Dekinga A, Koolhaas A, van der Meer J (2007) Dredging for edible cockles (Cerastoderma edule) on intertidal flats: short-term consequences of fisher patch-choice decisions for target and non-target benthic fauna. ICES J Mar Sci 64:1735-1742

Lejeusne C, Bock DG, Therriault TW, MacIsaac HJ, Cristescu ME (2011) Comparative phylogeography of two ascidians reveals contrasting invasion histories in North America. Biol Invasions 13:635-650

Luttikhuizen PC, Drent J, Baker AJ (2003) Disjunct distribution of highly diverged mitochondrial lineage clade and population subdivision in a marine bivalve with pelagic larvae. Mol Ecol 12:2215-2229

Luttikhuizen PC, Campos J, van Bleiswijk J, Peijnenburg KTCA, van der Veer HW (2008) Phylogeography of the common shrimp, Crangon crangon (L) across its distribution range. Mol Phylogenet Evol 46:1015-1030

Maggs CA, Castilho R, Foltz D et al (2008) Evaluating signatures of glacial refugia for North Atlantic benthic marine taxa. Ecology 89:S108-S122

Marko PB, Hoffman JM, Emme SA, McGovern TM, Keever CC, Cox LN (2010) The 'Expansion-Contraction' model of Pleistocene biogeography: rocky shores suffer a sea change? Mol Ecol 19:146-169

Martin PR, McKay JK (2004) Latitudinal variation in genetic divergence of populations and the potential for future speciation. Evolution 58:938-945

Ménot G, Bard E, Rostek F, Weijers JWH, Hopmans EC, Schouten S, Damsté JSS (2006) Early reactivation of European rivers during the last deglaciation. Science 313:1623-1625

Nikula R, Väinölä R (2003) Phylogeography of Cerastoderma glaucum (Bivalvia: Cardiidae) across Europe: a major break in the Eastern Mediterranean. Mar Biol 143:339-350

Nikula R, Strelkov P, Väinölä R (2007) Diversity and trans-arctic invasion history of mitochondrial lineages in the North Atlantic Macoma balthica complex (Bivalvia: Tellinidae). Evolution 61:928-941

Olsen JL, Stam WT, Coyer JA et al (2004) North Atlantic phylogeography and large-scale population differentiation of the seagrass Zostera marina L. Mol Ecol 13:1923-1941

Olsen JL, Zechman FW, Hoarau G, Coyer JA, Stam WT, Valero M, Aberg P (2010) The phylogeographic architecture of the fucoid seaweed Ascophyllum nodosum: an intertidal 'marine tree' and survivor of more than one glacial-interglacial cycle. J Biogeogr $37: 842-856$
Piersma T, Koolhaas A, Dekinga A, Beukema JJ, Dekker R, Essink K (2001) Long-term indirect effects of mechanical cockle-dredging on intertidal bivalve stocks in the Wadden Sea. J Appl Ecol 38:976-990. doi:10.1046/j.1365-2664.2001.00652.x

Reise K (1985) Tidal flat ecology. Ecol Stud 54, Springer, Berlin

Reitzel AM, Darling JA, Sullivan JC, Finnerty JR (2008) Global population genetic structure of the starlet anemone Nematostella vectensis: multiple introductions and implications for conservation policy. Biol Invasions 10:1197-1213

Reusch TBH, Bolte S, Sparwel M, Moss AG, Javidpour J (2010) Microsatellites reveal origin and genetic diversity of Eurasian invasions by one of the world's most notorious marine invader, Mnemiopsis leidyi (Ctenophora). Mol Ecol 19:2690-2699. doi: 10.1111/j.1365-294X.2010.04701.x

Riginos C, Henzler CM (2008) Patterns of mtDNA diversity in North Atlantic populations of the mussel Mytilus edulis. Mar Biol 155:399-412

Rogers AR (1995) Genetic evidence for a pleistocene population explosion. Evolution 49:608-615

Rogers AR, Harpending H (1992) Population growth makes waves in the distribution of pairwise genetic differences. Mol Biol Evol 9:552-569

Roman J, Palumbi SR (2004) A global invader at home: population structure of the green crab, Carcinus maenas, in Europe. Mol Ecol 13:2891-2898

Rozas J, Sánchez-Delbarrio JC, Messeguer X, Rozas R (2003) DnaSP, DNA polymorphism analyses by the coalescent and other methods. Bioinformatics 19:2496-2497

Smietanka B, Zbawicka M, Wolowicz M, Wenne R (2004) Mitochondrial DNA lineages in the European populations of mussels (Mytilus spp.). Mar Biol 146:79-92

Sousa R, Dias S, Antunes JC (2006) Spatial subtidal macrobenthic distribution in relation to abiotic conditions in the Lima estuary, NW of Portugal. Hydrobiologia 559:135-148

Strasser M (2002) Reduced epibenthic predation on intertidal bivalves after a severe winter in the European Wadden Sea. Mar Ecol Prog Ser 241:113-123

Strasser M, Reinwald T, Reise K (2001) Differential effects of the severe winter of 1995/96 on the intertidal bivalves Mytilus edulis, Cerastoderma edule and Mya arenaria in Northern Wadden Sea. Helgol Mar Res 55:190-197

Tarnowska K, Chenuil A, Nikula R, Féral JP, Wołowicz M (2010) Complex genetic population structure of bivalve (Cerastoderma glaucum) living in highly fragmented lagoon habitat. Mar Ecol Prog Ser 406:173-184

Thieltges DW (2006) Parasite induced summer mortality in the cockle Cerastoderma edule by the trematode Gymnophallus choledochus. Hydrobiologia 559:455-461

Väinölä R, Strelkov P (2011) Mytilus trossulus in Northern Europe. Mar Biol 158:817-833

Wilson J (1981) Temperature tolerance of circatidal bivalves in relation to their distribution. J therm Biol 6:279-286

Zhang D, Hewitt GM (2003) Nuclear DNA analyses in genetic studies of populations: practice, problems and prospects. Mol Ecol 12:563-584 